\title{
Potential impact of parents' lifestyle on the occurrence of leukemia in their children
}

\section{Potencjalny wpływ stylu życia rodziców na występowanie białaczki u ich dzieci}

\author{
Dorota Polak ${ }^{1, A-D \oplus}$, Ilona Hajok ${ }^{2, A-D \oplus}{ }^{\text {, Agata Piekut }}{ }^{3, C-F \oplus}$, Anna Spychała, ${ }^{3, B-C \oplus}$, \\ Małgorzata Ćwieląg-Drabek ${ }^{3, \mathrm{C}-\mathrm{F}}$ \\ ${ }^{1}$ Student Research Group, Department of Environmental Health, Faculty of Health Sciences in Bytom, Medical University \\ of Silesia, Katowice, Poland \\ ${ }^{2}$ Centre for Technology Transfer, Medical University of Silesia, Katowice, Poland \\ ${ }^{3}$ Department of Environmental Health, Faculty of Health Sciences in Bytom, Medical University of Silesia, Katowice, \\ Poland
}

A - Research concept and design, B - Collection and/or assembly of data, C - Data analysis and interpretation, $D$ - Writing the article, $E$ - Critical revision of the article, $F$ - Final approval of article

Polak D, Hajok I, Piekut A, Spychała A, Ćwieląg-Drabek M. The Potential Impact of Parents' Lifestyle on the Occurrence of Leukemia in Their Children. Med Sr. 2020; 23(1-4): 18-25. doi: 10.26444/ms/140166

\begin{abstract}
Introduction. The most common cancers in children are leukemias, which account for approximately $25 \%$ of all cancers diagnosed in children in Poland. During 1999-2016, a total of 4,905 children and adolescents fell ill with leukemia, of whom 1,479 died. The study assumes that the exposure of parents in the pre-contraceptive period and the exposure of their children in the prenatal period to environmental carcinogens may influence the development of leukemia.

Objective. The aim of this study was to analyze the occurrence of health risk factors in the families of children suffering from leukemia, caused by environmental pollution or the lifestyle of their parents.

Materials and method. To achieve the assumed goal, a questionnaire study was conducted among 100 parents/ legal guardians of children treated for leukemia.

Results. Statistical analyses of the data obtained showed a statistically significant correlation between the occurrence of leukemia in a child and: the child's age at diagnosis of the disease $(p<.047)$, consumption of vegetables from their own cultivation by the respondents and their children $(p<.048)$, and the use of plant protection products and artificial fertilizers in arable fields, allotment and home gardens owned by the respondents $(p<.003)$.

Conclusions. In order to reduce the health risk associated with the occurrence of neoplastic diseases of the blood in the population of children, actions should be taken to increase the awareness of the general population about the presence of carcinogenic and haematotoxic factors in the human living environment.
\end{abstract}

\section{Key words}

risk factors, parents, environmental exposure, life style, child, leukemia

\section{Streszczenie}

Wprowadzenie i cel pracy. Najczęstszymi nowotworami występującymi w populacji dzieci są białaczki, które stanowią ok. $25 \%$ wszystkich nowotworów rozpoznawanych u dzieci w Polsce. W latach 1999-2016 na białaczkę zachorowało łącznie 4905 dzieci i młodzieży, z czego 1479 zmarło. W pracy założono, że ekspozycja rodziców w okresie przedkoncepcyjnym oraz ich dzieci w okresie prenatalnym na czynniki rakotwórcze w środowisku może wpływać na rozwój białaczki. Celem pracy była analiza występowania czynników ryzyka zdrowotnego w rodzinach dzieci chorych na białaczkę, spowodowanych zanieczyszczeniem środowiska lub stylem życia rodziców dzieci.

Materiał i metody. Aby osiągnąć założony cel, przeprowadzono badanie ankietowe wśród 100 rodziców/ opiekunów prawnych dzieci leczonych z powodu białaczki.

Wyniki. Analiza statystyczna danych uzyskanych w badaniu kwestionariuszowym wykazała istotną statystycznie korelację pomiędzy występowaniem białaczki u dziecka a: wiekiem dziecka w momencie rozpoznania choroby $(p<0,047)$, spożywaniem warzyw $z$ własnych upraw $(p<0,048)$ oraz stosowaniem środków ochrony roślin i nawozów sztucznych na polach uprawnych, w ogródkach działkowych i ogrodach przydomowych należących do respondentów $(p<0,003)$.

Wnioski. W celu zmniejszenia ryzyka zdrowotnego związanego z występowaniem chorób nowotworowych krwi w populacji dzieci należy podjąć działania mające na celu zwiększenie ogólnej świadomości populacji na temat obecności czynników rakotwórczych i hematotoksycznych w środowisku życia człowieka.

\section{Słowa kluczowe}

czynniki ryzyka, białaczka, styl życia, rodzice, dziecko, narażenie środowiskowe 


\section{INTRODUCTION}

Neoplastic diseases constitute a growing socio-economic problem worldwide as the primary cause of premature death in most developed countries and the secondary cause of mortality after cardiovascular diseases. Cancers are relatively rare in the paediatric population compared to the adult population. It is estimated that $1.5 \%-3 \%$ of the total number of malignant neoplasms are childhood cancers. Each year, approximately 300,000 new cases of cancer are diagnosed worldwide in the population of children aged $0-19$ years [14]. Childhood cancers are the second after accidents, injuries and poisoning, and the first disease cause of death in children $[4,5]$. In Poland, 1,100 - 1,200 new cases of childhood cancer are diagnosed every year. The most common cancers in children are leukemias, which account for approximately $25 \%$ of all cancers diagnosed in children in Poland. During 1999-2016, a total of 4,905 children and adolescents fell ill with leukemia, of whom 1,479 died. The data show that $30 \%$ of patients could not be cured. Both the incidence and deaths are more common among boys. In the morbidity statistics for 1999-2016, almost 57\% (2,788 cases) were boys, while girls constituted over $43 \%$ of the total (2,117 cases). Over the same timeframe, 898 deaths from leukemia were recorded in the population of boys (61\% of all deaths), and 581 (39\%) in the population of girls [6].

The most commonly diagnosed childhood malignancies include leukemias, brain cancers, lymphomas and solid tumours such as neuroblastoma or Wilms' tumour. According to statistics, $50 \%$ of the total number of neoplasms in the population up to 18 years of age are malignancies of the haematopoietic system, including leukemias which, depending on the age group analyzed, account for $25 \%-30 \%$ of the total number of neoplasms in the child population, followed by lymphomas (15\%), Hodgkin's lymphoma (2-3\%) and myelodysplastic syndromes (approx. 10\%) [5, 7, 8].

Among the factors influencing the formation of cancer in children, environmental factors are increasingly more often mentioned, apart from the occurrence of genetic mutations. Among the factors connected with parental lifestyle, maternal alcohol consumption during pregnancy is associated with a significantly increased risk of acute myeloid leukemia (AML) in young children. According to data from the International Agency for Research on Cancer (IARC), published in the World Cancer Report in 2014, environmental factors (including lifestyle) play a key role in the formation of $80-90 \%$ of malignant tumours [9]. There are many harmful factors in the human living environment which may have a negative impact on health in particularly vulnerable groups, including children [10]. It is considered that the incidence of cancer occurs in people with a genetic predisposition who have been exposed to harmful environmental factors during their utero or early childhood $[11,12]$. This fact is confirmed by a large number of diagnosed cases of leukemia in children in the first years of life. The peak incidence of acute lymphoblastic leukemia (ALL) is between the ages of 2-5 years, while acute myeloid leukemia $(\mathrm{AML})$ is most common in children under 1 year of age. In addition, parental exposure to environmental risk factors, especially during the preconception and prenatal periods, is also expected believed to play a role $[13,14,15]$.

Environmental factors that have a proven impact on the incidence of leukemia in children include ionizing radiation and chemical agents, such as particulate matter fraction $\mathrm{PM}_{10}$, polychlorinated biphenyls (PCBs), benzene, toluene and pesticides [16-20]. Exposure to ionizing radiation is one of the environmental risk factors most often associated with the occurrence of leukemias, especially acute myeloid leukemia. Research indicates that the risk of developing cancer is greatest when exposure to ionizing radiation occurs prenatally and in early childhood [21]. Research also focuses on the use of x-rays in the diagnosis of children, in the prenatal and postnatal periods, which may be a risk factor in the development of leukemia $[13,15]$. According to the IARC and the United States Department of Health and Human Services (HHS), the chemical factors responsible for the formation of haematopoietic system neoplasms include: particulate matter fraction $\mathrm{PM}_{10}$, arsenic and its compounds (in particular arsane), benzene, chemicals contained in cigarette smoke, mixtures containing polycyclic aromatic hydrocarbons (PAHs) - e.g. coal pitch, tar, asphalts, vinylbenzene (styrene) [22-29]. Some studies also indicate a relationship between children's environmental exposure to PCBs and an increased risk of developing acute lymphoblastic leukemia [17, 30].

The growing number of new cases of children suffering from malignant blood cancers requires the implementation of effective preventive measures, which should take into account the limitation of the influence of modifiable factors, such as environmental pollutants, that affect the occurrence of blood cancer in the population of children. Actions to reduce the concentrations of toxic pollutants are long-term actions; therefore, the best method which can be achieved in a short time would be to raise public awareness of environmental threats to health, because early exposure to harmful compounds present in the environment of human existence may not only contribute to the occurrence of childhood cancers, but can also cause the development of cancer later in life [31].

The study assumes that the exposure of parents in the pre-contraceptive period and the exposure of their children in the prenatal period to environmental carcinogens may influence the development of leukemia. The aim of this study was to analyze the occurrence of health risk factors in the families of children suffering from leukemia, caused by environmental pollution or the lifestyle of their parents assuming that the lifestyle decisions taken by parents will also affect their children.

\section{MATERIALS AND METHOD}

To achieve the assumed goal, a questionnaire study was conducted among 100 parents / legal guardians of children treated for leukemia, and who agreed to participate in the study, in the medical centres involved in the treatment of leukemia in children in the Silesian Province of southwestern Poland:

- Dr. Edward Hanke Center of Pediatrics and Oncology in Chorzów (CPOC)

- Prof. Stanisław Szyszko Independent Public Clinical Hospital No. 1 in Zabrze, Medical University of Silesia in Katowice (IPCH)

- John Paul II Upper Silesian Child Health Centre in Katowice (USCHC), Medical University of Silesia in Katowice.

The questionnaires were collected during the treatment, 
directly in the hospital. The proprietary questionnaire was carried out each time personally by a qualified nurse. For the purposes of this study, 100 questionnaires were collected, of which:

- 60 questionnaires in the Department of Pediatric Haematology and Oncology in USCHC.

- 25 questionnaires in the Department of Oncology, Haematology and Chemotherapy in IPCH.

- 15 questionnaires in the Department of Pediatric Haematology and Oncology in CPOC.

The questionnaire was also conducted among the parents / legal guardians of 100 healthy children - a control group. The research material used in statistical analyses was based on an anonymous proprietary questionnaire consisting of 26 questions. The database included both quantitative (measurable) variables, such as: age of the child, mother and father, age at which the child fell ill, number of cigarettes smoked per day by a parent, and qualitative (non-measurable) variables, such as: child's gender, diagnosed disease entity (in the case of sick children), parents' education and professional status. The questionnaire also included questions about lifestyle, which concerned: smoking, having a backyard or allotment garden, or a farm, and the vegetables cultivated there. The variable "child's onset age" was recoded in age groups, in accordance with the guidelines of the National Cancer Registry: 0-4 years, 5-9 years, $10-14$ years and 15-19 years.

The Chi Square test and.05 level of significance was used in the statistical analysis of the data. If the relationship between variables was statistically significant, the strength of the relationship (correlation) was checked using the V-Cramer or $\Phi$-Yule coefficient. Statistical analysis of the collected material was carried out using Microsoft Office (MS Excel) and Statistica 12 (StatSoft, Poland), with the addition of the Medical Kit.

\section{RESULTS}

Characteristics of the studied population. The questionnaire study covered parents / legal guardians of 100 children suffering from leukemia, as well as parents / legal guardians of 100 healthy children as the control group. Taking into account the rarity of malignant neoplasms in the population of children, the study group can be assessed as numerous.

Analyzing the education of the surveyed parents, the most numerous group of mothers (44\%) were women with secondary education, the least numerous with vocational education (20\%). The education of the fathers differed from that of the mothers; the most numerous group were fathers with vocational education (37\%), 33\% of fathers had secondary education, $25 \%$ had higher education, and $2 \%$ of fathers had primary education. The most frequently indicated types of professional work performed by mothers were white collar work (27\%) and physical work (25\%). $24 \%$ of the surveyed mothers declared that they were unemployed, and $16 \%$ had never taken up a job. $5 \%$ of the respondents worked in agriculture, and one of the mothers was a pensioner. Of the 97 fathers, $66 \%$ were blue collar workers, $27 \%$ white collar workers and $4 \%$ farmers. Retirees, disability pensioners and those never working professionally constituted the remaining $3 \%$ of the surveyed group of men.
Table 1. Characteristics of the studied population: study group and control group

\begin{tabular}{|c|c|c|c|}
\hline Variables & $\begin{array}{l}\text { Study group } \\
\quad(N=100)\end{array}$ & $\begin{array}{l}\text { Control group } \\
\qquad(N=100)\end{array}$ & $\begin{array}{l}\text { Both groups } \\
\qquad(\mathrm{N}=200)\end{array}$ \\
\hline $\begin{array}{l}\text { gender: } \\
\text { girls } \\
\text { boys }\end{array}$ & $\begin{array}{l}44 \% \\
56 \%\end{array}$ & $\begin{array}{l}49 \% \\
51 \%\end{array}$ & $\begin{array}{l}47 \% \\
53 \%\end{array}$ \\
\hline $\begin{array}{l}\text { average age [years]: } \\
\text { child } \\
\text { mother } \\
\text { father }\end{array}$ & $\begin{array}{c}9.5 \\
35.8 \\
38.5 \\
\end{array}$ & $\begin{array}{c}4.8 \\
32.4 \\
35.2\end{array}$ & $\begin{array}{c}7.1 \\
34.1 \\
36.8\end{array}$ \\
\hline $\begin{array}{l}\text { mother's education: } \\
\text { primary } \\
\text { vocational } \\
\text { secondary } \\
\text { higher }\end{array}$ & $\begin{array}{c}0 \% \\
20 \% \\
44 \% \\
36 \%\end{array}$ & $\begin{array}{l}1 \% \\
2 \% \\
32 \% \\
65 \%\end{array}$ & $\begin{array}{c}0.5 \% \\
11 \% \\
38 \% \\
50.5 \%\end{array}$ \\
\hline $\begin{array}{l}\text { father's education: } \\
\text { primary } \\
\text { vocational } \\
\text { secondary } \\
\text { higher } \\
\text { no answer }\end{array}$ & $\begin{array}{c}2 \% \\
36 \% \\
32 \% \\
27 \% \\
3 \%\end{array}$ & $\begin{array}{c}5 \% \\
11 \% \\
34 \% \\
50 \%\end{array}$ & $\begin{array}{c}3.5 \% \\
23.5 \% \\
33 \% \\
38.5 \% \\
1.5 \%\end{array}$ \\
\hline $\begin{array}{l}\text { smoking by mother: } \\
\text { yes } \\
\text { no }\end{array}$ & $\begin{array}{l}25 \% \\
75 \%\end{array}$ & $\begin{array}{l}25 \% \\
75 \%\end{array}$ & $\begin{array}{l}25 \% \\
75 \%\end{array}$ \\
\hline $\begin{array}{l}\text { smoking by father: } \\
\text { yes } \\
\text { no } \\
\text { no answer }\end{array}$ & $\begin{array}{c}40 \% \\
57 \% \\
3 \%\end{array}$ & $\begin{array}{l}31 \% \\
69 \%\end{array}$ & $\begin{array}{c}35.5 \% \\
63 \% \\
1.5 \%\end{array}$ \\
\hline
\end{tabular}

In the control group, both mothers and fathers most often had higher education, $65 \%$ and $50 \%$, respectively. The smallest percentage among the surveyed parents from the control group were those with primary education - $1 \%$ of mothers and $5 \%$ of fathers. White-collar work and physical work were the most frequently indicated types of professional work performed by mothers $-66 \%$ and $22 \%$ respectively. $7 \%$ of the surveyed mothers were unemployed, while $3 \%$ of mothers declared that they had never taken up a job. Moreover, $1 \%$ of the surveyed mothers worked in agriculture and one of the mothers was a student. Among the fathers, the majority of respondents were blue-collar and white-collar workers $-49 \%$ and $48 \%$ respectively, while $1 \%$ were farmers and unemployed. The questionnaire was answered by parents / legal guardians of 56 boys and 44 girls diagnosed with leukemia and parents / legal guardians of healthy boys and girls, 51 and 49 respectively, aged 0-19. For the purposes of statistical analyses, the population of children included in the study, both in the study group and in the control group, was divided into 4 age groups, in accordance with the guidelines of the National Cancer Registry. The youngest age group, 0-4 years, constituted $48 \%$ of the total in the study group and $60 \%$ of the total in the control group. 32\% were sick children and $20 \%$ healthy children aged 5-9 years, and the percentage of children aged $10-14$ years was $12 \%$ for sick children and $16 \%$ for healthy children. The smallest group, both in the case of the control group and the study group, were adolescents aged $15-19$, representing $4 \%$ and $10 \%$ of the total, respectively.

The study confirmed the results of other analyses, which indicate the most frequent occurrence of leukemia in children aged 2-5 years [5-8]. In the study population of sick children, leukemia was also most often diagnosed between the ages of 2-5, with the highest incidence of $20 \%$ in the group of 3 -year-olds (Fig. 1). The most common types of leukemia 


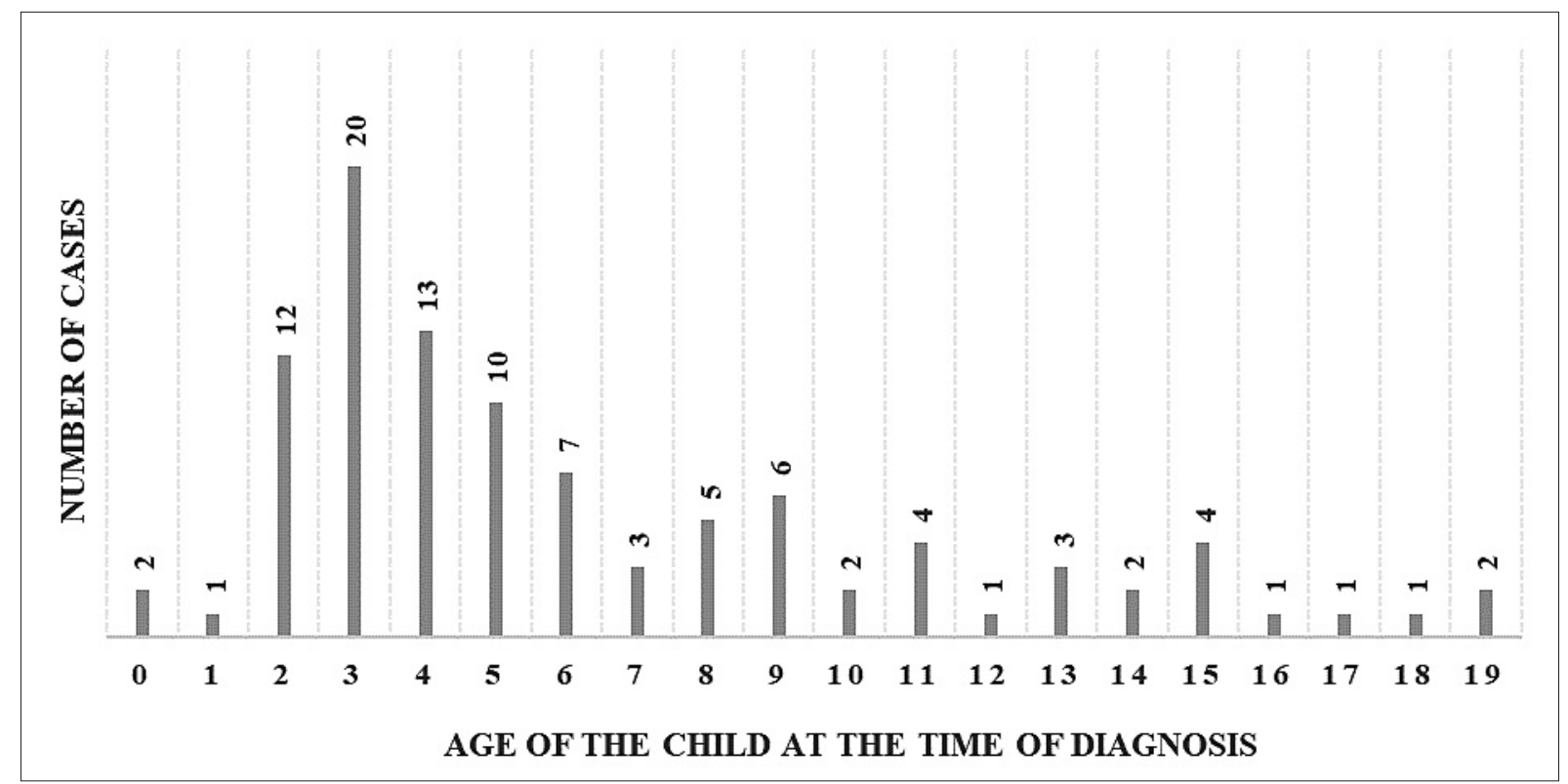

Figure 1. Characteristics of the studied population, taking into account the age of the child at the time of diagnosis

diagnosed in the study group were: lymphoblastic leukemia (C91) (35\% of the total), acute lymphoblastic leukemia (C91.1) (28\%) and cell leukemia of unspecified type (C95-17\%). Myeloid leukemia (C92) occured in 11\% of sick children, and acute myeloid leukemia (C92.1) in 8\%.

Results of the Questionnaire Survey. The study showed that the respondents and their children suffering from leukemia were exposed in the living environment to environmental factors that could influence the onset of the disease.

One of the factors is exposure to tobacco smoke [23, 27, 29 ], and among mothers in the study group as many as $25 \%$ of the respondents declared that they smoke. When asked about the number of cigarettes they smoke, 19 mothers say they smoke 10-17 cigarettes a day, and another 6 women stated that they smoke 2-6 cigarettes a day. As many as $15 \%$ of mothers admitted smoking during pregnancy which proves that their babies were exposed to toxic substances in tobacco smoke in the womb. The percentage of fathers declaring smoking cigarettes was significantly higher compared to mothers and amounted to $41 \%$. In the analyzed group of fathers declaring smoking, 24 of them smoked from 20-40 cigarettes a day, the remaining group $(\mathrm{N}=16)$ from $5-18$ cigarettes a day. Among all mothers in the control group, the same as in the study group, $25 \%$ declared that they smoke cigarettes; 15 mothers smoke 10-20 cigarettes a day, and 10 mothers 1-10 cigarettes. $5 \%$ of mothers surveyed admitted to smoking during pregnancy. In the case of fathers in the control group, $31 \%$ of them declared smoking.

Other factors that have proven influence on the formation of malignant neoplasms, including leukemia in children, are toxic substances present in the living environment or the parents' workplace. When asked about the presence of harmful substances in the workplace, most parents of sick children responded negatively (64\% of mothers and 66\% of fathers). On the other hand, $14 \%$ of women and $33 \%$ of men answered positively. $22 \%$ of women and $1 \%$ of men did not provide an answer. Among the harmful substances present in the work environment, the respondents most often mentioned heavy metals, i.e. lead, zinc and cadmium $(\mathrm{N}=13$ people). Artificial fertilizers and plant protection products were mentioned by 10 respondents. The fathers from the study group of sick children also reported that they are exposed to construction dust, coke dust and coal dust in the working environment. In the control group, $86 \%$ of mothers and $80 \%$ of fathers declared that they have no contact with harmful substances in the workplace.

A significant source of exposure to toxic substances, such as dioxins (PCDDs), polychlorinated biphenyls (PCBs) or polycyclic aromatic hydrocarbons (PAHs), with a proven impact on the formation of leukemia in children, is the incineration of plastic waste in home boiler rooms and heating furnaces [16-20]. When asked about the type of residential building where the parents / legal guardians live with their sick child, $55 \%$ of respondents answered that they live in a single-family house, $41 \%$ in a multi-family block, and $4 \%$ in a tenement house. The main source of heating an apartment / house, declared by $31 \%$ of respondents, was central heating from a combined heat and power plant, central heating from own boiler room was declared by $29 \%$ of respondents, gas heating (17\%), a coal stove (16\%), another form of heating (such as a fireplace with a mantle water) (4\%), electric heating (2\%), oil heating (1\%). Among the respondents who have a coal stove to heat their home, as many as $50 \%(n=8)$ declared burning plastic waste, such as PVC bottles and containers, other plastics and rubber products. In the control group, $32 \%$ of the respondents live in a singlefamily house, $61 \%$ in a multi-family block, $7 \%$ in a tenement house. $44 \%$ of respondents declared that the main source of heating their apartment / house is central heating from a combined heat and power plant, over $1 / 4$ of the respondents (27\%) have gas heating. $13 \%$ of parents declared having a coal stove, while central heating from their own boiler room was declared by $9 \%$, electric heating $-5 \%$, and another form of heating (such as a fireplace with a water jacket) $-2 \%$.

Scientific research shows that exposure to pesticide plant protection products can also have a significant impact on the formation of leukemia in children [11]. Among the respondents from the study group (parents of children with leukemia), $18 \%$ of parents own a farm, $25 \%$ a home 


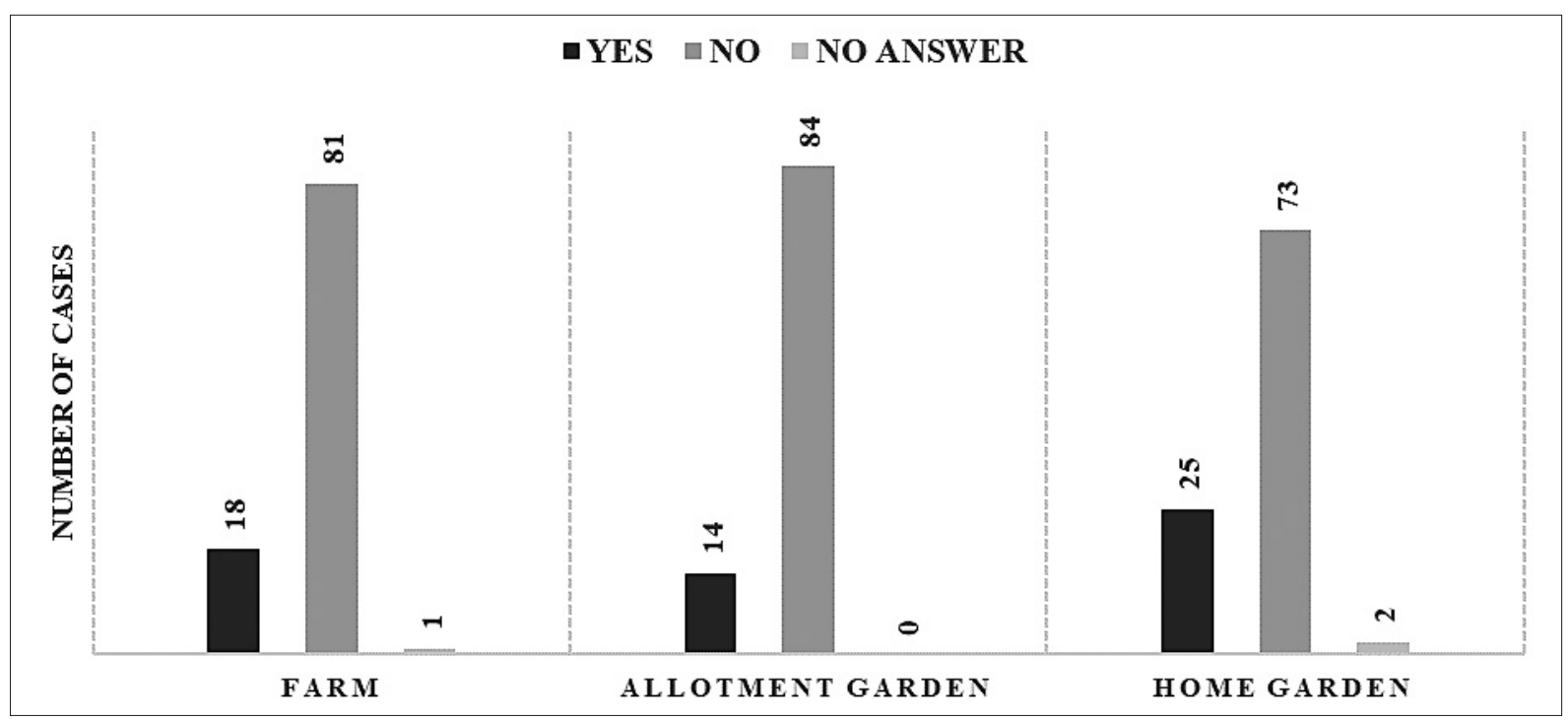

Figure 2. Structure of the answer to the question: 'Do you have a farm, allotment garden, home garden in which vegetables are grown?'

garden and $16 \%$ an allotment garden where vegetables are grown. (Fig. 2), and $91 \%$ of them declare that grown vegetables are part of their daily diet, the most commonly grown are parsley, carrots, cabbage, lettuce and chives.

In the analyzed group of parents of sick children, when asked about the use of chemicals such as plant protection products or fertilizers, as many as $1 / 3$ of respondents (31\%) replied that they use such agents in their farms, home gardens or allotments. In the control group, having a farm, home garden or allotment garden was declared by $5 \%, 16 \%$ and $5 \%$ of parents, respectively. Out of them, $62 \%$ of respondents consume self-grown vegetables every day. In the analyzed control group, 23\% replied that they use chemical plant protection products.

Arsenic contained, for example, in well water intended for drinking, which is not subject to mandatory control tests in Poland, is another factor that may adversely affect the health of children, influencing the occurrence of leukemia in this population group [22]. Among the surveyed parents of sick children, $8 \%$ have their own wells from which they draw drinking water. The water source for $91 \%$ of the respondents is the water supply network, while $1 \%$ have another source of water supplied to the home (using spring water). In the control group, the main source of water for $4 \%$ of respondents is a well, while $96 \%$ of respondents obtain water from the main water supply.

The last question in the survey concerned the subjective assessment of the quality of the environment in the place of residence. In the study group, $46 \%$ of respondents answered that they assessed the condition of the environment as good, $22 \%$ as sufficient, $12 \%$ as very good, and the same percentage of respondents assessed the condition of the environment as bad. $5 \%$ of respondents believe that the state of the environment in their place of residence is very bad, and 3\% of respondents do not have an opinion on this subject. In the control group, $7 \%$ of respondents assess the condition of the environment in the place of residence as very good. A comparable percentage of respondents believe that the quality of the environment is good, and sufficient (39\% and 38\%, respectively), while the answers: bad and very bad condition of the environment were indicated by $13 \%$ and $3 \%$ of the respondents, respectively.
Statistical analysis of questionnaire data. Statistical analyzes of the data obtained through the questionnaire study showed a statistically significant correlation between the type of diagnosed leukemia in a child and: the child's age at the diagnosis of the disease $(p<.047)$, consumption of vegetables from their own cultivation by the respondents and their children $(\mathrm{p}<.048)$, and the use of plant protection products and artificial fertilizers in arable fields, allotments and home gardens owned by the respondents $(\mathrm{p}<.003)$ (Tab. 2).

In the case of relationship between the type of leukemia and the age of the child at diagnosis, the strength of the correlation is $r=.24$, which indicates a weak correlation. The study also confirmed that the youngest children (in the $0-4$ and 5-9 age groups) are much more likely to suffer from leukemia (Tab. 3), which is consistent with the results of many studies [5-8].

The obtained results show that in children who eat vegetables from home crops or allotment gardens in their

Table 2. Relationship between the influence of selected environmental factors present in the environment of the studied population and the type of diagnosed blood cancer in children

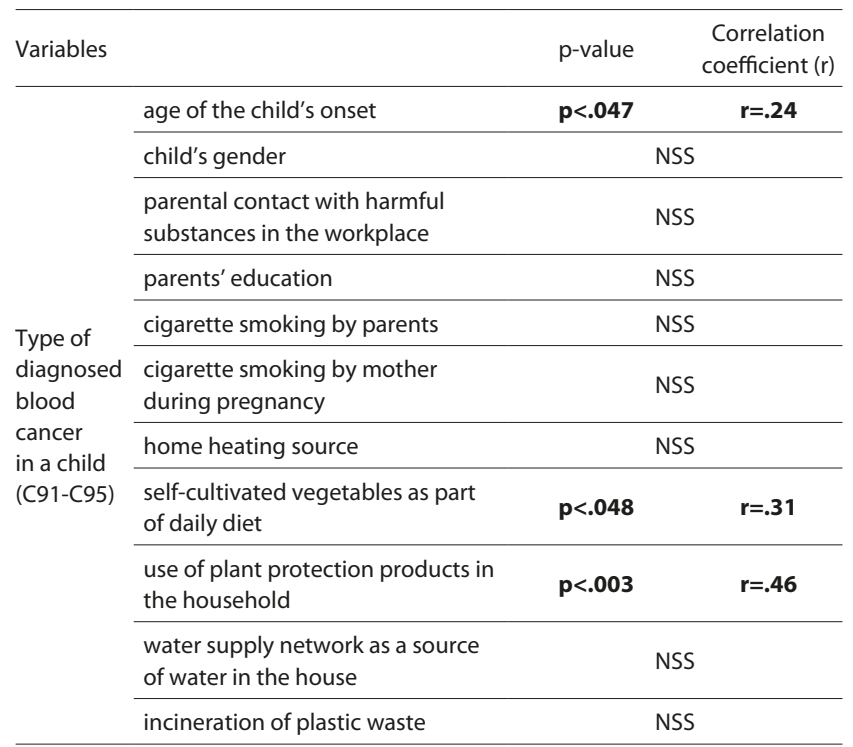

NSS - no statistical significance 
Table 3. Prevalence of leukemias in the population of children by type of leukemia and by age groups.

\begin{tabular}{lcccccc}
\hline \multirow{2}{*}{ Type of leukemia } & \multicolumn{5}{c}{ Child's age at the time of diagnosis } \\
[years]
\end{tabular}

*age groups according to the National Cancer Registry

daily diet, lymphoblastic leukemia was much more often diagnosed $(90 \%$ of the sick children consumed vegetables from own cultivation) and myeloid leukemia (100\% of children). The relationship between the type of leukemia and the consumption of vegetables from own crops in the daily diet indicates an average correlation ( $r=.31)$ (Tab. 4). In addition, all parents who declared the consumption of vegetables from their own crops also confirmed application of plant protection products in their households.

Table 4. Consumption of self-cultivated vegetables in a child's daily diet in the various type of diagnosed leukemia

\begin{tabular}{lccc}
\hline \multirow{2}{*}{ Type of leukemia } & \multicolumn{2}{c}{$\begin{array}{c}\text { Consumption of self-cultivated } \\
\text { vegetables in daily diet [N] }\end{array}$} \\
\cline { 2 - 4 } & yes & no & Total \\
\hline lymphoblastic leukemia & 35 & 4 & 39 \\
\hline myeloid leukemia & 9 & 0 & 9 \\
\hline leukemia of unspecified cell type & 8 & 4 & 12 \\
\hline Total & $\mathbf{5 2}$ & $\mathbf{8}$ & $\mathbf{6 0}$ \\
\hline
\end{tabular}

Statistical analysis was also performed to check whether smoking by the parents or smoking by the mother during pregnancy could influence the occurrence of blood cancer in children (Tab. 5).

Table 5. Relationship between selected environmental factors present in the environment of the studied population, and the diagnosed blood cancer in children

\begin{tabular}{|c|c|c|c|}
\hline Variables & & p-value & $\begin{array}{l}\text { Correlation } \\
\text { coefficient ( } r)\end{array}$ \\
\hline \multirow{6}{*}{$\begin{array}{l}\text { Diagnosed } \\
\text { blood cancer } \\
\text { in a child } \\
\text { (yes/no) }\end{array}$} & $\begin{array}{l}\text { parental contact with harmful } \\
\text { substances in the workplace }\end{array}$ & \multicolumn{2}{|r|}{ NSS } \\
\hline & cigarette smoking by parents & \multicolumn{2}{|c|}{ NSS } \\
\hline & $\begin{array}{l}\text { cigarette smoking by mother during } \\
\text { pregnancy }\end{array}$ & $p<.018$ & $\mathrm{r}=.36$ \\
\hline & home heating source & \multicolumn{2}{|r|}{ NSS } \\
\hline & $\begin{array}{l}\text { water supply network as a source of } \\
\text { water in the house }\end{array}$ & \multicolumn{2}{|c|}{ NSS } \\
\hline & incineration of plastic waste & \multicolumn{2}{|r|}{ NSS } \\
\hline
\end{tabular}

NSS - no statistical significance

Analysis of the obtained results also showed a statistically significant correlation between smoking by the mother during pregnancy and the occurrence of leukemia in the study group, compared to the control group $(\mathrm{p}<.018)$. The value of the correlation coefficient indicates a moderate correlation $(\mathrm{r}=.36)$. In both groups, of all smoking mothers, those of children with leukemia reported smoking during pregnancy more often (15.75\%), compared to mothers of healthy children (5.25\%) (Tab. 6).

Table 6. Cigarette smoking by mothers during pregnancy in the study and control group

\begin{tabular}{lccc}
\hline \multirow{2}{*}{ Group } & \multicolumn{3}{c}{ Smoking during pregnancy [N] } \\
\cline { 2 - 4 } & yes & no & in all \\
\hline control & 5 & 95 & 100 \\
\hline study & 15 & 85 & 100 \\
\hline in all & $\mathbf{2 0}$ & $\mathbf{1 8 0}$ & $\mathbf{2 0 0}$ \\
\hline
\end{tabular}

There was no statistically significant correlation between the occurrence of leukemia in children and parents' education.

\section{DISCUSSION}

Neoplastic diseases in the population of children and adolescents up to 18 years of age constitute a challenge for modern pediatric oncology and haematology, as well as for public health specialists. The most common neoplastic disease of the haematopoietic system is leukemia, which is also the first cause of cancer death in the population of children under 15 years of age. Analysis of data collected by the National Cancer Registry confirms the trends in developed countries regarding the number of cases and deaths caused by leukemia in the population of children and adolescents up to 18 years of age $[5,6,7]$. In Poland, during 1999-2016, leukemia accounted for $33 \%$ of all cancer cases, which were responsible for $29 \%$ of deaths in this age group. Thanks to the establishment of the Polish Paediatric Group for the Treatment of Leukemia and Lymphomas and the development of new treatment regimens, the number of deaths caused by blood cancer in Poland has been reduced. In the 1970 s and 1980 s, approx. $70 \%$ of children suffering from leukemia failed to be cured; now, leukemia deaths represent approx. $20 \%[6,32,33]$.

The literature data show that the most common leukemia in children is lymphoblastic leukemia, with the peak incidence of this type of cancer between the ages of 2-5 $[5,7,8]$. Statistical analyses showed that $63 \%$ of children in the study group suffered from lymphoblastic leukemia. In addition, children in the $0-4$ and 5-9 age groups became ill much more often than children in the other age groups, and the largest group at the time of falling ill were children in the third year of life.

It is now known that not only genetic mutations but also environmental hazards are the factors responsible for developing leukemia. The time that usually elapses from exposure to environmental risk factors to the diagnosis of the disease is usually from a few to several years. Therefore, the incidence of leukemia in children at such an early stage of life indicates that the exposure of parents to environmental carcinogens in the preconception and prenatal periods could play a significant role $[13,15]$.

Along with the technological progress, urbanization and chemicalisation of agriculture, the number and levels of xenobiotic concentrations in the human living environment increase. Lack of public awareness of harmful substances present in the immediate environment may have a negative impact on the health of future generations [10]. 
Among the carcinogens influencing the occurrence of leukemia in children is tobacco smoke. Despite the widespread knowledge about its harmfulness to the health of smokers and passively exposed people, the study showed that out of a100 surveyed mothers of sick children, as many as $15 \%$ admitted that they had smoked cigarettes during pregnancy, and $25 \%$ still smoke, which means that children were exposed in prenatal period and / or are in early childhood (passive smoking). Also, $41 \%$ of the surveyed fathers of children suffering from leukemia admitted that they smoke. According to research conducted in Poland and abroad, substances contained in nicotine and cigarette smoke have proven carcinogenic effects. The components of tobacco smoke have a negative effect on the bone marrow and morphology elements, and as a result may be a significant cause of cancer of the haematopoietic system, in particular leukemia [23, 27, 29].

Although the statistical analyses carried out in this study did not show any correlation between the occurrence of a child's disease and the exposure of the parents / legal guardians to the above-mentioned factors at the workplace, it should be noted that occupational exposure may overlap with home exposure, and all the factors mentioned by the respondents have proven carcinogenic effects, and many of them are among the leading place on the list of agents and chemicals recognized by the International Agency for Research on Cancer as confirmed carcinogenic and haematotoxic in humans [34].

Since the second half of the 20th century, synthetic plant protection products have been widely used in industrial agriculture all over the world. The studies carried out so far have confirmed the relationship between exposure to plant protection products and the increased risk of certain types of cancer $[17,35]$. Plant protection products are widely used not only by farmers in commercial crops, but also by people with allotments and home gardens, as evidenced by the study. Moreover, among the owners of farms, allotments or home gardens, almost all (91\% of respondents) consume self-cultivated vegetables as part of their daily diet. The use of plant protection products and artificial fertilizers by parents / legal guardians and the occurrence of leukemia in children indicates the existence of a relationship. The conducted analyses also showed a statistically significant relationship between the occurrence of leukemia in children and the consumption of vegetables from own crops.

In the conducted questionnaire survey, $97 \%$ of respondents live in the Silesian Province, which is important in the etiology of leukemia in children due to the fact that particulate matter is the factor having a proven carcinogenic effect, which can significantly increase the incidence of the disease. The latest report of the World Health Organization (WHO), assessing air quality in cities around the world, according to the average annual concentrations of particulate matter $\left(\mathrm{PM}_{2.5}\right)$, indicates that as many as 36 out of 50 of the most polluted cities in Europe are located in Poland, of which 12 are in the Silesian Province [25]. According to WHO and IARC, air pollution by particulate matter has been classified as a human carcinogen [36]. Due to the fact that the study population lives in the most polluted province in Poland, the respondents and their children are more exposed to carcinogens from the air, than residents of other provinces. According to the National Cancer Registry statistical data, the Silesian Province is in the top three provinces of the 16 provinces in Poland with the highest number of leukemia cases in children [6]. It is surprising that almost $60 \%$ of respondents assessed the condition of the environment in their place of residence as good or very good, which may indicate a lack of awareness among the respondents of environmental hazards occurring in their immediate surroundings.

In order to reduce the health risk influencing the formation of blood cancers in the population of children resulting from the environmental exposure of the general population to carcinogenic factors, actions should be taken to increase awareness about the presence of these factors in the human living environment, and also about ways to reduce exposure. Awareness-raising campaigns should be directed, in particular, to future parents who plan to have conscious and safe parenting. Environmental exposures in the prenatal period and in early childhood may be a more important risk factor for cancer incidence than exposure in adulthood. Identifying environmental risk factors that may increase the incidence of cancer in the paediatric population is an important step in reducing the overall burden of these diseases, both in childhood and in later life.

The study has several limitations. The questionnaire did not include questions about the duration of the child's treatment at the time of completing the questionnaire, drinking alcohol during pregnancy, parents' diet in the preconception period and during pregnancy, types of chemicals to which parents are exposed in the workplace. The study also does not specify the cumulative impact of all analyzed risk factors. The study should be classified as preliminary, requiring further extended analyses and supplements.

\section{CONCLUSIONS}

1. A statistical relationship has been demonstrated between the type of leukemia and age of the child at the diagnosis of the disease; Leukemia most often affects children aged $0-5$ years, which is also confirmed by the results of other researchers.

2. A statistical relationship has been demonstrated between the incidence of leukemia in children and the use of plant protection products in households.

3. In the study group, in contrast to the control group, a statistically significant correlation was found between smoking by mothers during pregnancy and the occurrence of leukemia in their child ( $\mathrm{p}<.018 ; \mathrm{r}=.36)$.

4. In order to reduce the health risk associated with the occurrence of neoplastic diseases of the blood in the population of children, actions should be taken to increase the general population awareness about the presence of carcinogenic and haematotoxic factors in the human living environment.

Conflicts of interest. The authors declare that the research was conducted in the absence of any commercial or financial relationships that could be construed as a potential conflict of interest.

Declaration of originality. This manuscript has not been published elsewhere and has not been simultaneously submitted for publication elsewhere. All tables and Figures are the authors' original work and no permissions are required. 
Funding. The study was funded by the Medical University of Silesia in Katowice, Poland (Grant No. KNW-1-094/ N/7/Z and KNW-1-99/N/9/Z).

\section{REFERENCES}

1. Kaatsch P. Epidemiology of childhood cancer. Cancer Treat Rev. 2010; 36(4): 277-285. doi: 10.1016/j.ctrv.2010.02.003

2.Szymborski J. Public health and population policy. Warsaw: Government Population Council; 2012. p. 40-64. [in Polish]

3. National Center for Injury Prevention and Control. Ten Leading Causes of Death and Injury. 2016. https://www.cdc.gov/injury/wis.... [access 20.10.2019]

4. Steliarova-Foucher E, Colombet M, Ries LAG., et al. International incidence of childhood cancer, 2001-10: a population-based registry study. Lancet Oncol. 2017; 18(6): 719-731. doi: 10.1016/S14702045(17)30186-9

5. Szymborski J, Didkowska J, Wojciechowska U. Malignant neoplasms in children and adolescents in Poland. Incidence and mortality from malignant neoplasms and the demographic situation of Poland. Warsaw: Government Population Council; 2014. p. 117-146. [in Polish]

6. Wojciechowska U, Didkowska J. Morbidity and mortality from malignant neoplasms in Poland. National Cancer Registry. Oncology Center - Institute of Maria Skłodowska-Curie. 2019. http://onkologia. org.pl/raport... [access: 09.10.2019]

7. Gupta S, Howard S, Hunger S, et al. Treating Childhood Cancers in Lowand Middle-Income Countries. In: Cancer: Disease Control Priorities. Third edition (Volume 3). Washington (DC): The World Bank; 2015. http://dcp-3.org/chapter/900/t... [access: 09.10.2019]

8. Israels T, Challinor J, Howard S, et al. Treating Children With Cancer Worldwide - Challenges and Interventions. Pediatrics 2015; 136(4): 607-610. doi: doi.org/10.1542/peds.2015-0300

9. Stewart BW, Wild CP, editor. World Cancer Report 2014. International Agency for Research on Cancer. Lyon: World Health Organization; 2014.

10. Strumylaite L. Cancer risk in relations to exposure to trace elements. Environ Med. 2011; 14(1): 7-12:

11. Commission for Environmental Cooperation. Toxic Chemicals and Children's Health in North America. A Call for Efforts to Determine the Sources, Levels of Exposure, and Risks that Industrial Chemicals Pose to Children s Health. CEC Project Report. 2006. http://www3.cec. org/islandora/... [access: 09.10.2019]

12. Gouveia-Vigeant T, Tickner J. Toxic chemicals and childhood cancer: A review of the evidence. A Publication of the Lowell Center for Sustainable Production. University of Massachusetts Lowell. 2013. https://sustainableproduction.... [access: 09.10.2019]

13. Norman RE, Ryan A, Grant K, et al. Environmental Contributions to Childhood Cancers. J Environ Immunol Toxicol. 2014; 1(4): 190-202. doi: $10.7178 /$ jeit. 17

14. Hunger SP, Mullighan CG. Acute Lymphoblastic Leukemia in Children. N Engl J Med. 2015; 373(16): 1541-1552. doi: 10.1056/NEJMra1400972

15. Jin MW, Xu SM, An Q, et al. A review of risk factors for childhood leukemia. Eur Rev Med Pharmacol Sci. 2016; 20(18): 3760-3764.

16. Schmieglow K, Vestergaard T, Nielsen SM, et al. Etiology of common childhood acute lymphoblastic leukemia; the adrenal hypothesis. Leukemia 2008; 22: 2137-2141. doi: 10.1038/leu.2008.212

17. Ward $\mathrm{MH}$, Colt JS, Metayer C, et al. Residential exposure to polychlorinated biphenyls and organochlorine pesticides and risk of childhood leukemia. Environ Health Perspect. 2009; 117(6): 1007-1013. doi: 10.1289/ehp.0900583
18. Chokkalingam AP, Bartley K, Wiemels JL, et al. Haplotypes of DNA repair and cell cycle control genes, $\mathrm{x}$-ray exposure, and risk of childhood acute lymphoblastic leukemia. Cancer Causes Control 2011; 22(12): 1721-1730. doi: 10.1007/s10552-011-9848-y

19. Pearce MS, Salotti JA, Little MP, et al. Radiation exposure from CT scans in childhood and subsequent risk of leukaemia and brain tumours: a retrospective cohort study. Lancet 2012; 380(9840): 499-505. doi: 10.1016/S0140-6736(12)60815-0

20. Vinceti M, Rothman KJ, Crespi CM, et al. Leukemia risk in children exposed to benzene and PM10 from vehicular traffic: a case-control study in an Italian population. Eur J Epidemiol. 2012; 27(10): 781-790. doi: 10.1007/s10654-012-9727-1

21. Preston DL, Cullings H, Suyama A, et al. Solid cancer incidence in atomic bomb survivors exposed in utero or as young children. J Natl Cancer Inst. 2008; 100(6): 428-436. doi: 10.1093/jnci/djn045

22. Moore LE, Lu M, Smith AH. Childhood Cancer Incidence and Arsenic Exposure in Drinking Water in Nevada. Arch Environ Health An Int J. 2002; 57(3): 201-206. doi: 10.1080/00039890209602937

23. Sikorska-Jaroszyńska MHJ, Mielnik-Błaszczak M, Krawczyk D, et al. Passive smoking as an environmental health risk factor. Ann Agric Environ Med. 2012; 19(3): 547-550.

24. Heck JE, Wu J, Lombardi C, et al. Childhood Cancer and Traffic-Related Air Pollution Exposure in Pregnancy and Early Life. Environ Health Perspect. 2013; 121(11-12): 1385-1391. doi: 10.1289/ehp.1306761

25. Deziel NC, Rull RP, Colt JS, et al. Polycyclic Aromatic Hydrocarbons in Residential Dust and Risk of Childhood Acute Lymphoblastic Leukemia. Environ Res. 2014; 133: 388-395. doi: 10.1016/j.envres.2014.04.033

26. Malagoli C, Malavolti M, Costanzini S, et al. Increased incidence of childhood leukemia in urban areas: a population-based case-control study. Epidemiol Prev. 2015; 39(4 Suppl 1): 102-107.

27. Rumrich IK, Viluksela M, Vahakangas K, et al. Maternal Smoking and the Risk of Cancer in Early Life - A Meta-Analysis. PLoS One. 2016; 11(11): e0165040. doi: 10.1371/journal.pone.0165040

28. D'andrea MA, Reddy GK. Health Risks Associated With Benzene Exposure in Children: A Systematic Review. Glob Pediatr Health. 2018; 5: 2333794X18789275. doi: 10.1177/2333794X18789275

29. Khani Y, Pourgholam-Amiji N, Afshar M, et al. Tobacco Smoking and Cancer Types: A Review. Biomedical Res Ther. 2018; 5(4): 2142-2159.

30. Szymala I. The incidence of leukemia and malignant lymphoma in children in the Silesia Province in terms of environmental pollution. Dissertation. Medical University of Silesia in Katowice. Bytom, Poland 2018.

31. Carpenter DO, Bushkin-Bedient S. Exposure to chemicals and radiation during childhood and risk for cancer later in life. J Adol Health. 2013; 52(5): 21-29. doi: 10.1016/j.jadohealth.2013.01.027

32. Topiłko A, Radwańska U, et al. Morphological analysis and differential diagnosis of ac. leukemia in children by electron microscopy. J Submicroscop Cytology 1974; 6: 191.

33. Radwańska U, Michalewska D, et al. The results of intensive treatment of 426 children with acute lymphoblastic leukemia. Acta Haemat Pol. 1981; 12: 175. [in Polish]

34. International Agency for Research on Cancer. IARC Monographs on the Identification of Carcinogenic Hazards to Humans. Agents Classified by the IARC Monographs, 2019, Volumes 1-124. https://monographs. iarc.fr/age... [access: 10.09.2019]

35. Ki-Hyun K, Kabir E, Jahan SA. Exposure to pesticides and the associated human health effects. Sci Total Environ. 2017; 575: 525-535. doi: 10.1016/j.scitotenv.2016.09.009

36. World Health Organization. WHO's Urban Ambient Air Pollution database Update. 2018. https://www.who.int/airpolluti... [access: 10.09.2019] 